Journal of Social Sciences 5 (4): 390-397, 2009

ISSN 1549-3652

(C) 2009 Science Publications

\title{
Occupational Stress and its Effects towards the Organization Management
}

\author{
${ }^{1}$ Azizi Yahaya, ${ }^{2}$ Noordin Yahaya, ${ }^{2}$ Kamariah Arshad, ${ }^{2}$ Jasmi Ismail, \\ ${ }^{3}$ Saini Jaalam and ${ }^{4}$ Zurihanmi Zakariya \\ ${ }^{1}$ Faculty of Education, Universiti Teknologi Malaysia, 81310 UTM Skudai Johor Malaysia \\ ${ }^{2}$ Faculty of Business Management, University Technology Mara (Melaka), Malaysia \\ ${ }^{3}$ Academy of Language Study, University Technology Mara (Melaka), Malaysia \\ ${ }^{4}$ Ministry of Youth and Sport
}

\begin{abstract}
Problem statement: The aim of this study is to find out the causes of occupational stress within the organization and the implication on job satisfaction and intention to leave and absenteeism. The researcher chooses 100 employees in Companies Commission of Malaysia, a statutory body which regulated company and businesses. Approach: All questionnaires are gathered after 2 weeks after it was distribute. Pearson product moment correlation to find out correlations and Multiple Linear Regression Technique were used to find out effect between variables. The finding indicates that factor such as external environment contribute to the occupational stress. This external factor is beyond the control of the organization. Results: The finding showed that occupational stress does not have direct effect on intention to leave and absenteeism but have direct negative effect on job satisfaction. Job satisfaction has negative effect on intention to leave and absenteeism. Some recommendation needed to be applied by management to reduce the number of turnover. Conclusion: First organization need to increase job satisfaction by reducing occupational stress. By reducing stress companies can reduce the level of intentional to leave and absenteeism.
\end{abstract}

Key words: Occupational stress, job satisfaction, intention to leave and absentism

\section{INTRODUCTION}

The Companies Commission of Malaysia Suruhanjaya Syarikat Malaysia (SSM) is a statutory body which regulated companies and businesses. SSM, which came into operation on 16 April 2002, is a statutory body formed as a result of a merger between the Registrar Of Companies (ROC) and the Registrar Of Businesses (ROB) in Malaysia. The main activity of SSM is to serve as an agency to incorporate companies and register businesses as well as to provide company and business information to public.

The topic of Occupational Stress and Job Satisfaction is always of interest in the employee and workplace. In this company, the employee has problem regarding the facilities such as lift where they need to share with other organization staff and create difficulties to them especially during climax time. This is because the organization don't have own building where the building is shared with other organization and public. Yet, the organization will move to the new building in 2010 in order to ensure the employee satisfied during work.

Occupational stress which defined as perceived onthe-job anxiety. Work stress appears to have become a more pervasive problem in recent years, judging by much survey done on the subject. Occupational stress arises when demand exceed abilities, while job-related strains are reactions or outcomes resulting from the experiences of stress ${ }^{[1]}$.

Stress refers to the generalized, patterned, unconscious mobilization of the body's natural ability. Occupational stress defined as the harmful physical and emotional responses that occur when the requirement of the job do not match the capabilities, resources or needs of the worker ${ }^{[2]}$. From that definition, Occupational stress is chronic conditions caused by situation in the workplace that mat negatively affect an individual's job performance and their overall wellbeing.

In the study setting, a role is the set of task and behaviors that others expect a person to perform while doing a job ${ }^{[3]}$. This means that the role of individual in the workplace can affect their performance.

Corresponding Author: Azizi Yahaya, Department of Foundation Education, Faculty of Education,

University Technology Malaysia 81310 UTM, Skudai Johor, Malaysia

Tel: +60127570298 Fax: +607550542 
It is because role conflict occurs when a focal person responds with behavior that serves as inputs to the role senders' process. The role conflict occur when a person perceives that some of the job requirement are incompatible, resulting in greater anxiety, tension and ultimately, low job satisfaction ${ }^{[4]}$.

In addition, role ambiguity is experienced when the message that evaluators send are not clear or they give incomplete information ${ }^{[5]}$. Employee who are not clear with their job are easy to get stress because they don't understand what they need to do actually.

The next variable that discuss in this research is job satisfaction. Job satisfaction arises when individual perceives his or her job as fulfilling values that are considered important to that individual ${ }^{[6]}$. Job satisfaction is one of the criteria of establishing a healthy organizational structure in $\mathrm{n}$ organization. It is because, in any organization, job satisfaction is very important I order to produce quality worker as well as the product.

The rate of turnover is quite high. I recognize that one of the factors is within the workplace itself. Factors such as communication at workplace, environment, assignment given, salary and benefit received not satisfy the employee. The employee will dissatisfy if the assignment received is too many and at the same time they need to meet dateline ${ }^{[6]}$. Little supervision and less support from manager in conducting the assignment will need to the high level of stress and dissatisfaction.

Adding up, the number who feels to intent to leave the organization is seriously hampering the productivity expansion. Even employee just feels to intent in their heart, it will show that the organization is not satisfying them anymore ${ }^{[7]}$.

Besides that, in the organization there is some employee where they assume that they jib is only temporary only which means that's their job in this organization just temporary until they get better job. It shows the low commitment within them ${ }^{[8]}$. This type of employee will lead to the low performance as well productivity. Some employee seems to take for granted with their job and as a result, the task given will not accomplish properly and cannot meet the dateline. This will affect organization image especially which deal with public ${ }^{[9]}$.

\section{MATERIALS AND METHODS}

The main purpose of this study is to determine the effect of occupational stress job satisfaction that occurs in this company. This chapter outlines the methodology, which used to test the hypotheses in that proposed in chapter 1 . The following term will guide in the discussion.

Instrument reliability and validity: Several instruments were utilized to collect the data for this research. Part 1 of the questionnaire asked for demographic data. Part 2 contained job satisfaction questionnaire. Part 3 contained items from occupational stress questionnaire. Part 4 asked a question for intention to leave. Finally part 5 was a question on intention to leave.

The reliability test was test by Alpha Cronbach. The result of the test, only one question from part 3 (occupational stress) because other question is not reliable where it less than 0.7. It same with Role ambiguity and external environment where only one question can be selected ${ }^{[10]}$.

Sampling technique: The sampling technique that is applied for this study is a sample random sampling. Each person in the population has equal and independent chance to be part of the sample and the population members are similar to one another on important variable ${ }^{[11]}$. So, to ensure high degree of representatives ands avoid wasting time, simple random sampling are chosen because this technique requires the researcher to select the population of the employee in headquarters $^{[12]}$.

Population and sample: The population of worker in these companies was a group of respondent who are employed in this company. At this company, employees from headquarters are chosen to be a sample of population in this study. The sample frame and the sample utilized were $(\mathrm{N}=100)$ in this company. These entire employees are choosing from headquarters only.

Data collection: The data from this study were collected by distributed by hand a set of questionnaire on 17 March 2009, Tuesday. A cover letter was accompanied together for each set of questionnaire. The cover letter asked the employee to complete all the set of questionnaire and return as soon as possible. The respondent was asked to answer the entire set ands were given some times to complete the questionnaire. The questionnaire is in two languages which is Bahasa Malaysia and English. After some time, when the respondent return the questionnaire, the data was analyzed by using SPSS software in order to get the reliability and validity as well as the result of the finding. 
Table 1: The level of Reliability of variables in the questionnaire

\begin{tabular}{lll}
\hline Variables & $\mathrm{N}$ & Reliability \\
\hline Occupational stress & 100 & 0.502 \\
Job satisfaction & 100 & 0.719 \\
Intention to leave & 100 & 0.864 \\
Absenteeism & 100 & 0.791 \\
External environment & 100 & 0.864 \\
Role ambiguity & 100 & 0.510 \\
\hline
\end{tabular}

Pilot study: Before questionnaires are distributed, a pilot study was conducted. I choose from 10-15 samples to answer the question. During that time, I was with them so that they can ask whatever question they don't understand. The question which frequently ask by respondent will be consider and change if necessary.

Reliability table: The reliability of the research instrument for the final research was support by the fact that Cronbach's alpha can be seen in the Table 1 .

As seen above, occupational stress and role ambiguity is below than 0.7 . Because of the question is not reliable, I decide to find other alternative. The past researcher had done the same thing which is only one question for one variable because the variable is not reliable if use more than one ${ }^{[13]}$.

Due to the factor, the researcher decides to choose only one question for the variable (I'm not clear with my job duty).same with occupational stress question where only one is select (in the overall, I feel stress in the workplace. It is because due to some mistake, if choose more than two question, the question still not reliable

Data analysis: Collected survey forms were checked for completeness of data and proper data entry. The Statistical Packages for Social Sciences (SPSS) was used to make appropriate calculation of statistics including means, median, ranges, frequency and standard deviation.

Pearson correlation tests were used to determine the relationship between variables such as occupational stress and intention to leave, occupational stress and absenteeism, job satisfaction and intention to leave, job satisfaction and absenteeism and between occupational stress and job satisfaction. The level of significant is using a one-tail test. In addition, data on the variable of demographic were analyzed to determine the percentage of respondent. The result used to make valuable recommendations to the management.

After the variable are test using Pearson correlation, if there is significant relationship, the variable can be test for second test by using Multiple Linear Regression to get the Beta value for each relationship.
Table 2: Years of service in the organization

\begin{tabular}{lcc}
\hline Years & Frequency & Percentage \\
\hline Below 1 year & 25 & 25.0 \\
1-5 years & 47 & 47.0 \\
6-10 years & 18 & 18.0 \\
11 and above & 10 & 10.0 \\
\hline Total & 100 & 100.0 \\
\hline
\end{tabular}

Table 3: Type of organization respondent work

\begin{tabular}{lcc}
\hline Numbers & Frequency & Percentage \\
\hline 1 & 23 & 23.0 \\
2 & 34 & 34.0 \\
3 & 27 & 37.0 \\
4 and above & 16 & 16.0 \\
\hline Total & 100 & 100.0 \\
\hline
\end{tabular}

Table 4: Level of current position

What is your current position level?

\begin{tabular}{lcc} 
& Frequency & Percentage \\
\hline Executive & 35 & 35.0 \\
Non executive & 65 & 65.0 \\
\hline Total & 100 & 100.0 \\
\hline
\end{tabular}

Table 5: The distribution of respondent salary

Salary

\begin{tabular}{lcc}
\hline Salary & Frequency & Percentage \\
\hline RM100-RM1500 & 41 & 41.0 \\
RM1501-RM2500 & 36 & 36.0 \\
RM2501-RM3500 & 14 & 14.0 \\
RM3501-RM4500 & 7 & 7.0 \\
RM4501 and above & 2 & 2.0 \\
\hline Total & 100 & 100.0 \\
\hline
\end{tabular}

Table 6: Comparing of mean

\begin{tabular}{lllll}
\hline Variable & Mean & SD & Variance & Number \\
\hline Occupational stress & 2.4300 & 1.27330 & 1.621 & 100 \\
Job satisfaction & 3.3543 & 0.71080 & 0.505 & 100 \\
Intention to leave & 3.0463 & 0.69094 & 0.477 & 100 \\
Absenteeism & 3.1888 & 0.62291 & 0.388 & 100 \\
Role ambiguity & 1.8800 & 0.94580 & 0.895 & 100 \\
External environment & 3.6650 & 1.02999 & 1.061 & 100 \\
\hline
\end{tabular}

Research finding: The purpose of this chapter is to analyze the results of these surveys sent to the 100 employee. Of 100 surveys sent to them, all is completed and returned over a two week period. There was no missing data. The following information is taken from the data contained in this questionnaire.

The majority respondent has been work for at least 2 organizations which is $34 \%$ out of $100 \%$ as seen in the Table 2. Current position level-based on the respondents $65(65 \%)$ of the 100 were non executive as seen in the Table 3.

Salary-BASED on the respondents $41(41 \%)$ of the 100 were RM1501-RM2500 as seen in the Table 4.

Comparing of variables, means and standard deviations: Following on the Table 5 and 6 are the 
variables, means of the scale, standard deviations and variance of the data collected and the number of respondents.

Item $1,5,6$, variable construct the occupational stress variables. Item 3 and 4 is the key to measures intention to leave and absenteeism.

\section{RESULTS}

Correlation result: The data for variable chosen for this study were tested using Pearson correlation analysis. The Table 7 shows the correlation result for each variable. If the variables have relationship, second test will be testing by using regression. The symbol of (**) show the correlation between variables and must do second test.

Table 8 shows that between occupational stress, intention to leave and absenteeism. The result shows that correlation of occupational stress and intention to leave is $r=-0.24$ is very weak and $p(0.45)>0.01$ indicate there is no significant relationship between occupational stress and intention to leave at $\alpha=0.01$.

As for relationship between occupational stress ands absenteeism is $\mathrm{r}-.0 .42$ and it shows that weak and negative relationship. Since $p(0.339)>0.01$, it shows that there is no significant with a significant relationship between occupational stress and absenteeism at $\alpha=0.01$.

While the strength of relationship between intentions to leave and absenteeism is $r=0.662$. It shows that the strength between intentions to leave and absenteeism is moderate. Since $p(0.00)<0.01$, it shows that there is significant with a significant relationship between intentions to leave and absenteeism at $\alpha=0.01$.

Table 7: Relationship between occupational stress, intention to leave and absenteeism

\begin{tabular}{llccc}
\hline Correlations & & $\begin{array}{l}\text { Occupational } \\
\text { stress }\end{array}$ & $\begin{array}{l}\text { Intention } \\
\text { to leave }\end{array}$ & Absenteeism \\
\hline Occupational & Pearson correlation & 1.000 & -0.024 & -0.042 \\
stress & Sig. (1-tailed) & & 0.405 & 0.339 \\
& $\mathrm{~N}$ & 100.000 & 100.000 & 100.000 \\
Intention to & Pearson correlation & -0.024 & 1.000 & $0.662^{* *}$ \\
leave & Sig. (1-tailed) & 0.405 & & 0.000 \\
& $\mathrm{~N}$ & 100.000 & 100.000 & 100.000 \\
\hline **: Correlation is significant at the 0.01 level (1-tailed) &
\end{tabular}

Table 8: Relationship between job satisfaction, intention to leave and absenteeism

\begin{tabular}{lllrr}
\hline & & & Intention \\
Correlations & & Job satisfaction & \multicolumn{1}{c}{ to leave } & Absenteeism \\
\hline Job & Pearson & & & \\
satisfaction & correlation & 1 & $-0.258^{* *}$ & $-0.259 * *$ \\
& Sig. (1-tailed) & & 0.005 & 0.005 \\
& $\mathrm{~N}$ & 100 & 100.000 & 100.000 \\
\hline **: Correlation is significant at the 0.01 level (1-tailed) &
\end{tabular}

Table 8 shows that between job satisfaction, intention to leave and absenteeism. The result shows that correlation of job satisfaction and intention to leave is $r=-0.258$ is very weak and $p(0.005)<0.01$ indicate there is significant relationship between occupational stress and intention to leave at $\alpha=0.01$.

As for relationship between job satisfaction ands absenteeism is $\mathrm{r}-0.259$ and it shows that weak and negative relationship. Since $\mathrm{p}(0.005)<0.01$, it shows that there is significant with a significant relationship between occupational stress and absenteeism at $\alpha=0.01$.

Table 9 shows that relationship of occupational stress and role ambiguity and external environment. The result shows that the strength of relationship between occupational stress and role ambiguity $\mathrm{r}=0.379^{* *}$ and this shows that the weak relationship and $\mathrm{p}(0.00)<0.01$ and this shows that there is significant relationship between occupational stress and role ambiguity While the strength of relationship between occupational stress and external environment $r=-0168$ and this indicate that negative and weak. There is no significant relationship between occupational stress and external environment $\mathrm{p}(0.047)>0.01$

Table 10 shows the relationship between job satisfaction and occupational stress. Results shows that the strength of relationship between occupational stress and job satisfaction is weak and negative. $\left(\mathrm{r}=-0.218^{*}\right)$. The result also shows that $\mathrm{p}(0.015)<0.05$ and this indicate that there is no relationship between occupational stress and job satisfaction.

Table 11 shows that relationship of occupational stress and role ambiguity and external environment. The result shows that the strength of relationship between occupational stress and role ambiguity $\mathrm{r}=0.379^{* *}$ and this shows that the weak relationship and $\mathrm{p}(0.00)<0.01$ and this shows that there is significant relationship between occupational stress and role ambiguity While the strength of relationship between occupational stress and external environment $r=-0168$ and this indicate that negative and weak. There is no significant relationship between occupational stress and external environment $\mathrm{p}(0.047)>0.01$.

Table 9: Relationship between occupational stress, role ambiguity and external environment

\begin{tabular}{lllll}
\hline Correlations & & $\begin{array}{l}\text { Occupational } \\
\text { stress }\end{array}$ & $\begin{array}{l}\text { Role } \\
\text { ambiguity }\end{array}$ & $\begin{array}{l}\text { External } \\
\text { environment }\end{array}$ \\
\hline Occupational & Pearson & & & \\
Stress & correlation & 1 & $0.379^{* *}$ & $-0.168^{*}$ \\
& Sig. (1-tailed) & & 0.000 & 0.047 \\
& $\mathrm{~N}$ & 100 & 100.000 & 100.000 \\
\hline
\end{tabular}

**: Correlation is significant at the 0.01 level (1-tailed); *: Correlation is significant at the 0.05 level (1-tailed) 
Table 10: Relationship between occupational stress and job satisfaction

\begin{tabular}{llcc}
\hline Correlations & Job satisfaction & Occupational stress \\
\hline Job & Pearson correlation & 1 & $-0.218^{*}$ \\
satisfaction & Sig. (1-tailed) & & 0.015 \\
& $\mathrm{~N}$ & 100 & 100.000 \\
\hline
\end{tabular}

*: Correlation is significant at the 0.05 level (1-tailed)

Table 11: Multiple linear regression between job satisfaction and intention to leave

\begin{tabular}{|c|c|c|c|c|c|}
\hline \multirow{2}{*}{$\begin{array}{l}\text { Coefficients }{ }^{\mathrm{a}} \\
\text { Model }\end{array}$} & \multicolumn{2}{|c|}{ Unstandardized coefficients } & \multirow{2}{*}{$\begin{array}{l}\text { Standardized } \\
\text { coefficients } \\
\text { Beta }\end{array}$} & \multirow[b]{2}{*}{$t$} & \multirow[b]{2}{*}{ Sig } \\
\hline & B & Std. error & & & \\
\hline 1 (constant) & 3.8 & 0.325 & 11.950 & 0.000 & \\
\hline Job satisfaction & -0.251 & 0.095 & -0.258 & -2.641 & 0.010 \\
\hline
\end{tabular}

${ }^{\mathrm{a}}$ : Dependent variable: Intention to leave

Table 12: Multiple linear regression between job satisfaction and absenteeism

\begin{tabular}{llllll}
\hline \multicolumn{2}{c}{ absenteeism } & & & \\
Coefficients & Unstandardized coefficients & $\begin{array}{l}\text { Standardized } \\
\text { coefficients }\end{array}$ & & \\
Model & B & Std. error & Beta & \multicolumn{1}{c}{ t } & Sig. \\
\hline $1($ Constant $)$ & 3.950 & 0.293 & 13.475 & 0.000 & \\
Job satisfaction & -0.227 & 0.086 & -0.259 & -2.653 & 0.009 \\
${ }^{\mathrm{a}}$ : Dependent Variable: absenteeism & & & &
\end{tabular}

Table 11 shows multiple linear regression between job satisfaction and intention to leave The result shows that the relationship between job satisfaction and intention to leave; Job satisfaction $=3.887+(-0.258)$ intention to leave. The relationship show that's, job satisfaction give effect to intention to leave and there is a negative relationship.

Overall findings: First relationship is between job satisfaction and intention to leave. It shows the value of Beta is $\mathrm{B}=-0.258$. This means that, job satisfaction negatively effect intention to leave. Second relationship is between job satisfaction and absenteeism. It shows the value of Beta is $\mathrm{B}=-0.218$. This means that, job satisfaction negatively effect absenteeism.

Third relationship is between occupational stress and job satisfaction. It show the value of Beta is $B=-0.218$. This means that, occupational stress negatively effect job satisfaction. Occupational stress not affects intention to leave and absenteeism, but through job satisfaction, it may effect. It is because job satisfaction act as a mediator in this relationship.

Lastly, the relationship between external environment and occupational stress which show the value of Beta is $\mathrm{B}=-0.167$. This means that, external environment negatively effect occupational stress.

Table 12 shows multiple linear regression between job satisfaction and absenteeism. The result also shows that Relationship between job satisfaction and absenteeism; job satisfaction $=3.950+(-0.259)$ absenteeism; The relationship show that's, job satisfaction give effect to absenteeism and there is a negative relationship.
Table 13: Multiple Linear Regression between role ambiguity and occupational stress

\begin{tabular}{|c|c|c|c|c|c|}
\hline \multirow{2}{*}{$\begin{array}{l}\text { Coefficients }^{\mathrm{a}} \\
\text { Model }\end{array}$} & \multicolumn{2}{|c|}{ Unstandardized coefficients } & \multirow{2}{*}{$\begin{array}{l}\text { Standardized } \\
\text { coefficients } \\
\text { Beta }\end{array}$} & \multirow[b]{2}{*}{$\mathrm{t}$} & \multirow[b]{2}{*}{ Sig } \\
\hline & $\mathrm{B}$ & Std. error & & & \\
\hline 1(Constant) & 1.442 & 0.267 & & 5.396 & 0.000 \\
\hline Role ambiguity & 0.520 & 0.127 & 0.385 & 4.110 & 0.000 \\
\hline
\end{tabular}

${ }^{\mathrm{a}}$ : Dependent variable: Occupational stress

Table 14: Multiple linear regression between external environment and occupational stress

\begin{tabular}{|c|c|c|c|c|c|}
\hline \multirow{3}{*}{$\begin{array}{l}\text { Coefficients } \\
\text { Model }\end{array}$} & \multicolumn{2}{|c|}{ Unstandardized coefficient } & \multirow{2}{*}{\multicolumn{2}{|c|}{$\begin{array}{l}\text { Standardized } \\
\text { coefficients }\end{array}$}} & \multirow[b]{3}{*}{ Sig } \\
\hline & -- & & & & \\
\hline & B & Std. error & Beta & $\mathrm{t}$ & \\
\hline 1 (Constant) & 3.180 & 0.472 & & 6.744 & 0.000 \\
\hline External environment & -0.206 & 0.124 & -0.167 & -1.665 & 0.099 \\
\hline
\end{tabular}

${ }^{a}$ : Dependent variable: Occupational stress

Table 13 shows multiple linear regression between role ambiguity and occupational stress Result shows that the relationship between role ambiguity and occupational stress; occupational stress $=1.442+(0.385)$ role ambiguity. The relationship show role ambiguity does not contribute to occupational stress.

Table 14 shows that the multiple linear regression between external environment and occupational stress. The result shows that relationship between external environment and occupational stress; occupational stress $=3.180(-0.167)$ External environment; the relationship show external environment negatively contributes to the effect of occupational stress.

Recommendation: Based on the literature review and findings of this study, the researcher has made several recommendations that proposed to the Companies Commission of Malaysia. The recommendations are highlighted as below.

According to Goodman and Penning ${ }^{[14]}$, an important criterion related to employee absence and intention to leave is employee satisfaction that is employee with high level of job satisfaction is less likely to be absent and intent to leave the organization. In order to reduce the number of absenteeism and intention to leave the organization, organization must increase the level of job satisfaction so that employee will feel satisfy when working in the organization.

Table 15 shows that the multiple linear regression between occupational stress and job satisfaction. The result shows that relationship between occupational stress and job satisfaction; job satisfaction = $3.650+(-0.218)$ occupational stress; the relationship shows that occupational stress give effect to job satisfaction (negatively). 
Table 15: Multiple linear regression between occupational stress and job satisfaction

\begin{tabular}{llllll}
\hline \multicolumn{5}{c}{ Unstandardized coefficients } & \multicolumn{2}{l}{$\begin{array}{l}\text { Standardized } \\
\text { Coefficients }\end{array}$} \\
Model & - & B & Std. error & Befficients & \\
Beta & t & Sig \\
\hline 1(Constant) & 3.650 & 0.151 & & 24.199 & 0.000 \\
Occupational stress & -0.122 & 0.055 & -0.218 & -2.210 & 0.029 \\
\hline
\end{tabular}

${ }^{a}$ : Dependent variable: Job satisfaction

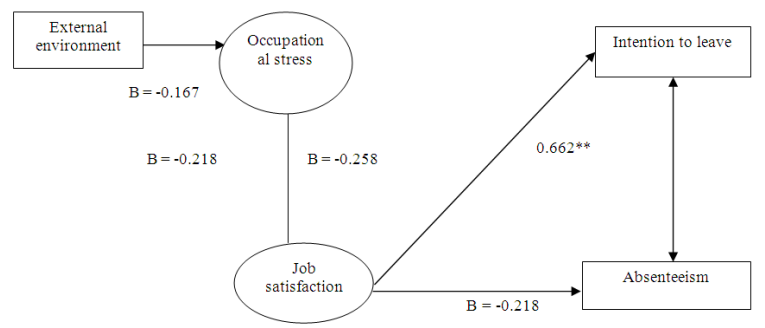

Fig. 1: Causes of occupational stress and its effect of job satisfaction, intention to leave and absenteeism

From the Fig. 1 explained that job satisfaction can be increase by give reward, recognition, give better salary and benefit and provide good facilities and so on.

Besides that, even occupational stress is not effect intention to leave and absenteeism, it may effect through job satisfaction because occupational stress effect job satisfaction. Organization must reduce the stress level so that job satisfaction will be high. Occupational stress can be reduced by give support to employee, give training, good communication in workplace, give extra leave, better salary and benefit and so on.

In addition, only one factor is recognizing in this research which is external environment. Organization must find as much as possible factor to reduce the level of occupational stress in the company so that future way can be predicted.

\section{DISCUSSION}

Factor influencing occupational stress: Stress can arises from one or more dimension and can be either internal or external. As stated by ${ }^{[2]}$ that stressor or cause of stress can range from catastrophic events to irritating incidents, however these stressor do not elicit a stress responses in the individual until the person appraises it as exceeding the available resources.

Role ambiguity is experienced when the message those evaluators send are not clear or they give incomplete information ${ }^{[10]}$. This is one of the factor contribute to occupational stress. Role ambiguity means employees are not clear with their job and responsibilities.
However, tension is created when demand of job or job environment exceed the capacity of the person to respond effectively ${ }^{[6]}$. This means that when employee exceed their capability, they easy to get stress or tension. Other studies have identified heave workload, urgency of work to be performed and role conflict, lack of social support, poor job fit, insufficient knowledge base and unsafe workplace.

According to ${ }^{[15]}$ the lack of job satisfaction is one of the variables that are strongly related to employee leaving a company. Other includes lack of organizational commitment and job involvement.

Effect of occupational stress on intention to leave and absenteeism: An increase in occupational stress has spillover effect on the both on the job and at home. occupational stress is a chronic condition caused by situation in the workplace that nay negatively affects an individual job performance and/or overall wellbeing.

Research has consistently demonstrated that excessive occupational stress has adverse effect for both physical and psychological wellbeing ${ }^{[14]}$. Besides that, it is estimated that occupational stress has cost organization billion of dollar through increase health care cost, higher rate of absenteeism and turnover and lower performance ${ }^{[12]}$ or employer, the cost are felt in term of low productivity, reduced profit, high rates of staff turnover and cost of recruiting and training replacement staff.

Effect of job satisfaction on intention to leave and absenteeism: According to Goodman and Penning ${ }^{[14]}$, an important criterion related to employee absence is employee satisfaction that is employee with high level of job satisfaction is less likely to be absent. Employee are easily to absent from work when they are not satisfy with some factor.

Indeed, some interest in job satisfaction is focused primarily on its impact on employee commitment, absenteeism, intention lo quit, and actual turnover. It shows that job satisfaction give negative effect if the employee has low job satisfaction.

Based on the researched ${ }^{[15]}$ the lack of job satisfaction is one variable that are strongly related to employee leaving the company and job involvement, which means that, employee who has low job satisfaction has intent to leave the organization.

Job satisfaction is usually defined as a pleasurable feeling that arises from one's workplace ${ }^{[16]}$ satisfaction has been show to be related to jobs performance, turnover and life dissatisfaction. From the previous research, we can say that, job satisfaction can effect towards employee performance and attitudes. 
Recommendation: Based on the literature review and findings of this study, the researcher has made several recommendations that proposed to the Companies Commission of Malaysia. The recommendations are highlighted as below:

- According to Goodman and Penning ${ }^{[14]}$, an important criterion related to employee absence and intention to leave is employee satisfaction that is employee with high level of job satisfaction is less likely to be absent and intent to leave the organization. In order to reduce the number of absenteeism and intention to leave the organization, organization must increase the level of job satisfaction so that employee will feel satisfy when working in the organization. Job satisfaction can be increase by give reward, recognition, give better salary and benefit, and provide good facilities and so on

- Besides that, even occupational stress is not effect intention to leave and absenteeism, it may effect through job satisfaction because occupational stress effect job satisfaction. Organization must reduce the stress level so that job satisfaction will be high. Occupational stress can be reduced by give support to employee, give training, good communication in workplace, give extra leave, better salary and benefit and so on

- In addition, only one factor is recognizing in this research which is external environment. Organization must find as much as possible factor to reduce the level of occupational stress in the company so that future way can be predicted

\section{CONCLUSION}

The finding from the study will provides the overall conclusion of the study. The cause of occupational stress is external environment where it was supported by hypothesis which is external environment negatively contributes to occupational stress. The job satisfaction effect intention to leave and absenteeism where it was supported by hypothesis which shows that is negative relationship between job satisfaction and intention to leave and negative relationship between job satisfaction and absenteeism.

The result also shows that the occupational stress is effect job satisfaction because from the result, hypothesis is accepted which is occupational stress negatively effect job satisfaction. Occupational stress indirectly effect intention to leave and job satisfaction but through job satisfaction, it may effect.
For the overall, it can be concluded that, when occupational stress increase, job satisfaction will decrease and can effect on intention to leave and absenteeism in this organization. As the conclusion, when occupational stress increases, job satisfaction will decrease and can effect on intention to leave and absenteeism in this organization. The factor of occupational stress is external environment which is something beyond organization control.

\section{REFERENCES}

1. Jensen, S. and J. McIntosh, 2007. Absenteeism in the workplace: Results from Danish sample survey data. Empir. Econ., 32: 125-139. DOI: 10.1007/s00181-006-0075-4

2. Mahmoud AL-Hussami, R.N., 2008. A study of nurses' job satisfaction: The relationship organizational commitment, perceived organizational support, transactional leadership, transformational leadership and level of education. Eur. J. Sci. Res., 22: 286-295. http://www.eurojournals.com/ejsr_22_2_14.pdf

3. Sokoya, S.K., 2000. Persona predictor of job satisfaction for the public sector manager. Eur. Manage. J., 21: 11-23.

4. Ciccotta, J.A., 1991. The link between individual occupational stress and organizational effectiveness. University of Winconsin.

5. Afzalur, R.M. and C. Psenika, 1996. A structural equations model of stress, locus of control, social support, psychiatric symptoms and propensity to leave a job. J. Soc. Physhol., 136: 69-84. http://www.ncbi.nlm.nih.gov/pubmed/8851448

6. Paula Silva, 2006. Effects of disposition on hospitality employee job satisfaction and commitment department of management, California State University, Northridge, California, USA. Int. J. Contemp. Hospit. Manage., 18: 317-328. http://d.wanfangdata.com.cn/NSTLQK_NSTL_QK 12624829.aspx

7. Bragg, D.M., 1982. Satisfaction, dissatisfaction: Application of Hertzberg's Dual factor theory to job change by practicing petroleum engineer.

8. Hemongway, M.A. and C.S. Smith, 1999. Organizational climate and occupational stressors as predictors of withdrawal behaviors and injuries in nurses. J. Occup. Org. Psychol., 72: 285-300. http://www.encyclopedia.com/doc/1G156743020.html

9. Gilmore, P.N., 2001. Managerial accountants, the equity theory, job satisfaction and intention to leave. Nove Southern University. 
10. Yew, L.T., 2002. Job satisfaction and attitude commitment. Acad. Taiwan Bus. Manage. Rev., 5. ISSN: 1813-0534

11. Albion, M.J., G.J. Fogarty, M.A. Machin and Jeff Patrick, 2008. Predicting absenteeism and turnover intentions in the health professions, Aus. Health Rev., 32: 271-281.

http://www.ncbi.nlm.nih.gov/pubmed/18447814

12. Hellman, C.M., 1997. Job satisfaction and intent to leave. J. Soc. Psychol., 137: 667-689. http://www.questia.com/googleScholar.qst;jsession id=K1Jdp2GY1DpV117WcB13nYQdsf6ypy1h0yb y7Xvq4XG8zJHBndDR!1899210215 ! 1048096975 ?docId=97934263

13. Bogg, J. and C. Cary, 1995. Job satisfaction, mental health and occupational stress among senior civil servants. Hum. Relat., 48: 327-341. http://psycnet.apa.org/?fa=main.doiLanding\&uid= 1995-35176-001
14. Affisco, J.F. and K.S. Soliman, 2006. Egovernment: A strategic operations management framework for service delivery. Bus. Process Manage. J., 12: 13-21. http://www.emeraldinsight.com.eserv.uum.edu.m

15. Parvatiyar, A. and J.N. Sheth, 2001. Conceptual Freamework of Customer Relationship Management. In: Customer Relationship Management: Emerging Concepts, Tools and Applications, Sheth, J.N., A. Parvatiyar and G. Shainesh (Eds.). Tata McGraw-Hill, New Delhi, pp: 3-25.

16. Peppers, D. and M. Rogers, 1995. A new marketing paradigm: Share of customer, not market share. Plann. Rev., 23: 14-18. 